\title{
THE FLUX OF ANTHROPOGENIC TRACE METALS INTO THE ARCTIC FROM THE MID-LATITUDES IN 1979/80
}

\author{
F. A. Akeredolu, L. A. Barrie, M. P. Olson and K. K. Oikawa \\ Atmospheric Environment Service, 4905 Dufferin Street, Downsview, Ontario, Canada, M3H 5T4 \\ and

\section{J. M. Pacyna and G. J. Keeler} \\ The University of Michigan, Department of Environmental and Industrial Health, Ann Arbor, \\ MI 48109-2029, U.S.A.
}

\begin{abstract}
The flux of trace metals into the Arctic atmosphere between 0 and $3.5 \mathrm{~km}$ altitude for the period July 1979-June 1980 was determined using a chemical transport modeling approach used previously for sulfur. The total annual flux of antimony, arsenic, cadmium, lead, zinc and vanadium into the Arctic from Eurasia was 4, 285. 47. 2400, 1350 and 474 tonnes, respectively. This represents $3.4,6.0,4.2,3.0,3.1$ and $1.7 \%$ of the source emissions, respectively. In contrast. the corresponding flux of sulfur was 2.2 million tonnes or $6.7 \%$ of the total emissions. The following percentage contributions to the total fux, of all six metals, by the source regions were calculated: western Europe (7-34\%), eastern Europe (42-54\%) and the Soviet Union $(21-39 \%)$. The model also showed that in addition to a late winter (February, March) maximum input to the Arctic. a peak was also observed in October. This peak was shown to have resulted from an unusual set of synoptic conditions, which produced a strong northerly flow into the Arctic around $0^{\circ}$ longitude in October 1979. Comparison of the model-predicted trace metal concentrations with a set of limited observations at existing sampling stations close to the Arctic Circle (namely Ny Alesund in Spitsbergen, Jergul, Skrova and Jan Mayen) showed agreement within a factor of 2-3.
\end{abstract}

Key word index: Trace elements, Lagrangian chemical transport model, Eurasian source contributions, Arctic metal deposition, height anomaly gradients.

\section{INTRODUCTION}

Arctic air pollution, commonly observed as Arctic haze, is now a well documented phenomenon (see reviews in Barric, 1986, 1992a; Heintzenberg, 1989; Ottar, 1989). It is a manifestation of the long range transport of pollution from mid-latitudinal sources particularly from Europe and northern Asia (Eurasia) to the Arctic on winds that favor transport to the north in winter over that in summer. Hence, the suspended particulate matter and acidic gases measured in the Arctic region undergo strong seasonal variations in concentration. Arctic air pollution is of concern because of its effect on climate, visibility, and potential ecological impacts on plants and wildlife.

Anthropogenic trace metals are an important component of particulate pollution in the Arctic atmosphere (Rahn and McCaffrey, 1980; Hoff et al., 1983; Pacyna and Ottar, 1985; Barrie and Hoff, 1985; Davidson et al., 1985; Barrie and Barrie, 1990). It is well known from studies performed near sources, such as smelters, that trace element emissions are potentially toxic to the local environment. The metals can accumulate in the environment, and thereby alter the conditions in which plants and wildlife grow.

Trace metals are also very important as tracers of long range transport of pollutants to the Arctic re- gions. Trace metal "signatures" (Lowenthal and Rahn, 1985 ) and the isotopic composition of lead (Sturges and Barrie, 1989; Sturges et al., 1994) in suspended particulate matter have been suggested as useful tools in identifying the origin of Arctic pollutants.

This study identifies the main sources and pathways of six primarily anthropogenic metals $(\mathrm{As}, \mathrm{Cd}, \mathrm{Pb}, \mathrm{Sb}$, $\mathrm{Zn}$, and $\mathrm{V}$ ) into the Arctic from Europe and the western Soviet Union (Eurasia). The calculations are performed using a chemical transport model that was previously applied to estimating the origin of sulfur in the Arctic for the year beginning July 1979-June 1980 for which trace element data are available (Barrie $e t$ al., 1989). Trace metal emission ficlds for Europe and the former western Soviet Union estimated by Pacyna $(1983,1984)$ were used in this work. A few questions were of prime interest: (i) what fraction of the total Eurasian emissions enters the Arctic at which longitude, altitude and time? (ii) how similar are the pathways into the Arctic of these metals to each other and to sulfur? and (iii) what fraction of the total input of each metal into the Arctic is deposited there?

There are several qualitative pieces of evidence that pollution in the Arctic originates mainly from the Eurasian continent. These include meteorological analyses that point to Eurasia as the predominant land mass upwind of the Arctic ocean during the 
period November to April (Rahn, 1982; Raatz and Shaw, 1984), aerosol trace element composition data (Rahn, 1981a; Lowenthal and Rahn, 1985), lead isotopic compositional data which are consistent with a Eurasian source (Sturges and Barrie, 1989; Sturges et $a l ., 1994)$ and chemical transport modeling (Barrie $e t$ al., 1989). In a case study of sulfur, Barrie et al. (1989) showed that sources in Europe and the Soviet Union contributed about $94 \%$ (compared with $6 \%$ from North American sources) of the total sulfur flux into the Arctic in $1979 / 80$. On that basis, only the trace metal fluxes from Eurasia are considered in this paper.

\section{THE MODEL}

The boundary of the Arctic domain through which the flux of trace metals is calculated is a $3.5 \mathrm{~km}$ vertical cylindrical surface around the Arctic Circle (latitude $66.5^{\circ} \mathrm{N}$ ) as shown in Figs 1 and 2 . Also shown is the modeling domain in the form of a rectangular horizontal grid with a spacing of $190.5 \mathrm{~km}$ at $60^{\circ} \mathrm{N}$.

In order to assess source region contributions Eurasia was divided into (1) west Europe defined as areas to the west of longitude $10^{\circ} \mathrm{E}$ with minor adjustments made to retain political boundaries intact; (2) east Europe, and (3) former Soviet Union, as shown in Fig. 3. Also shown in Fig. 3 are the stations for which trace metal concentrations were measured.

\section{Databases}

Gridded hemispheric wind analyses at the 100,85 , 70 and $50 \mathrm{kPa}$ levels are available from the Canadian Meteorological Center at $6 \mathrm{~h}$ intervals on a $381 \mathrm{~km}$ grid scale (at $60^{\circ} \mathrm{N}$ ) for 1979 and 1980 covering Eurasia, North America and adjacent oceans. The emission inventories were those reported by Pacyna $(1983,1984)$. These are shown in Figs 1 and 2, while the precipitation and mixing height databases were assembled from European sources as well as climatological background values. The European and former western Soviet Union precipitation data (available on a 6-h basis) were converted to daily amounts. The mixing heights were converted into monthly values and the 1980 emission inventory was supplied as an annual field. These three variables were supplied on the $150 \mathrm{~km}$ polar stereographic EMEP grid through the courtesy of A. Eliassen (Norwegian Meteorological Institute) and were converted to the $190.5 \mathrm{~km}$ CMC grid using quadratic interpolation in such a way that the emitted mass and precipitation totals were conserved. Annual climatological precipitation totals and mixing heights were inserted into the remaining grid areas of the eastern Soviet Union, the North Atlantic and Pacific Oceans. The North American and European databases were combined into hemispheric databases on a $190.5 \mathrm{~km}$ grid scale for 1980 .

\section{Concentration and flux calculations}

The long range transport Lagrangian model of Olson and Oikawa (1989) was used to compute the trace metal concentrations at three levels $(92.5,85.0$, $70.0 \mathrm{kPa}$ ) on the Arctic domain boundary at $20^{\circ}$ longitude intervals ( 18 points) every $6 \mathrm{~h}$ from July 1979 to June 1980 . This was done by computing the air parcel trajectories $5 \mathrm{~d}$ back in time from each of these points (see Figs 4-9 for examples). The trajectories moved up or down depending upon the vertical wind velocity. Beginning $5 \mathrm{~d}$ back in time and assuming that the trace metal concentrations were negligibly small at that time, an air parcel was then stepped along the trajectory over the gridded field of metal emission, precipitation rate, and mixing height. The air parcel acquired mass as it crossed the emission inventory field and lost mass by dry and wet deposition processes. The emission source term and dry deposition loss were "on" if the trajectory elevation was below the mixing depth and "off" if it was above.

Dry deposition was parameterized using the deposition velocity $\left(V_{\mathrm{d}}\right)$ which when multiplied by air concentration gave the dry removal (see Table 1). Wet removal was parameterized using scavenging ratios $(W=$ ratio of concentration in precipitation to that in air) and a daily precipitation amount $(P)$. It was assumed that about $11 \%$ of emissions $(f)$ were deposited within the source grid based on the results of dry deposition studies in the surrounding zones of lead and copper smelters in Poland (Pacyna et al., 1989).

Using the above procedure, the concentration of trace metals at 3 levels around the Arctic boundary is calculated every $6 \mathrm{~h}$. When multiplied by the meridional wind speed, this then yields the northward flux of metals through the boundary. The above procedure is mathematically summarized by the following differential equation:

$$
\mathrm{d} C / \mathrm{d} t=-\left\{V_{\mathrm{d}} / H+W P / H\right\} C+(1-f) Q / H
$$

where $H$ is the mixing height and $Q$ is the emission rate per grid square. This equation is integrated numerically using the trapezoidal rule and a 3 -h time step. Linear interpolation is used to obtain inter-grid point values when required.

\section{Model parameters}

The literature was reviewed for values of the dry deposition velocity and wet scavenging ratio for the metals of interest. These values as well as those selected for use in this work are summarized in Table 1. Some of the high values of dry deposition velocity reported in the literature are considered to be non-representative of the particles (usually fine particles) involved in long range transport into the Arctic because particles which have high deposition velocity would readily be removed by sedimentation. Similarly, low values of wet scavenging ratios reported in measurements done at urban locations are thought to be biased by the high surface ambient concentrations that are found at such locations which are most likely to be much higher than the cloud-level concentrations of those species (Barrie and Schemenauer, 1989; Barrie, 1992a). These points were taken into consideration 

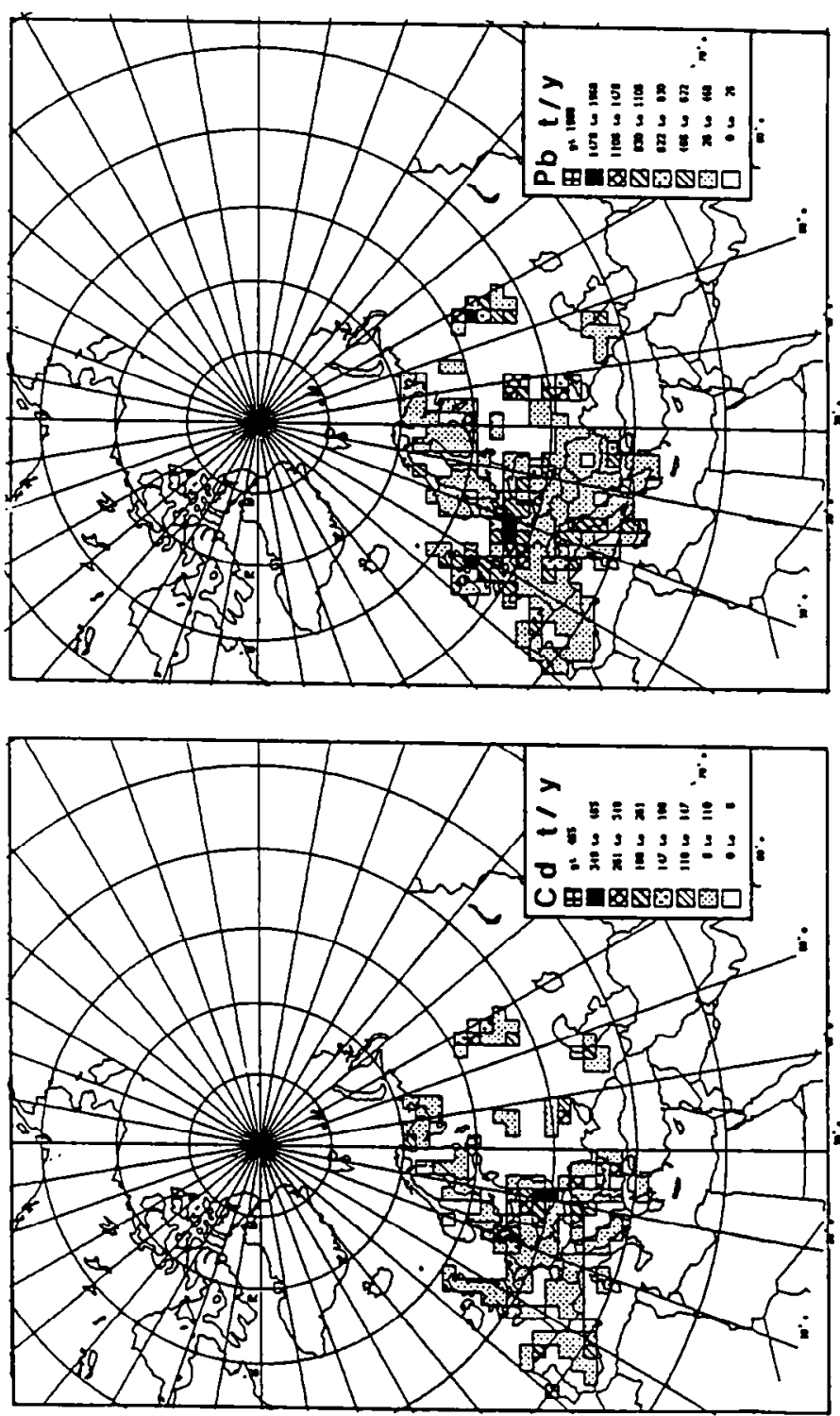

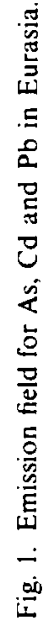

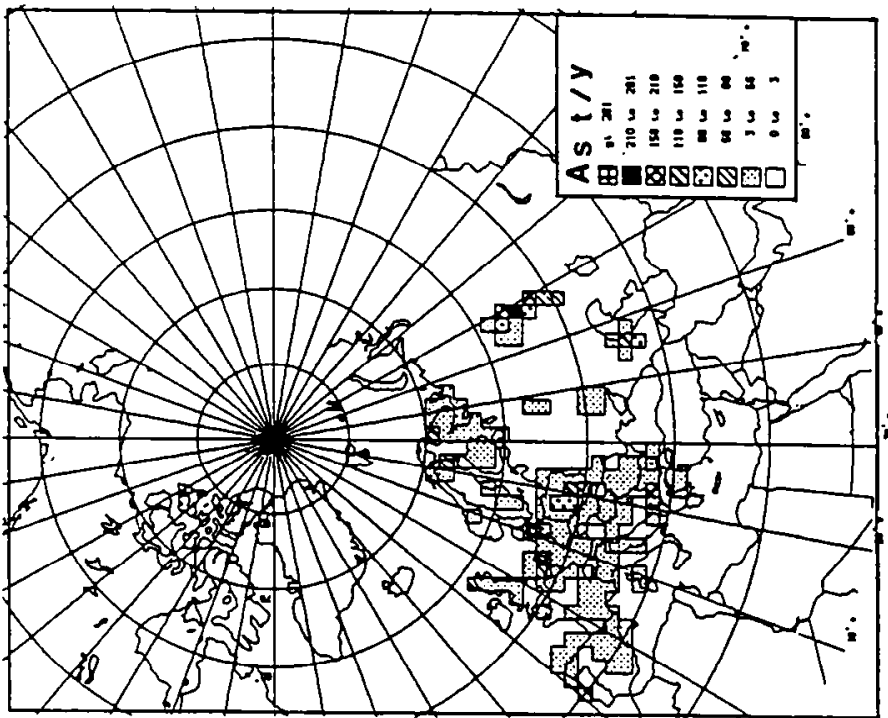



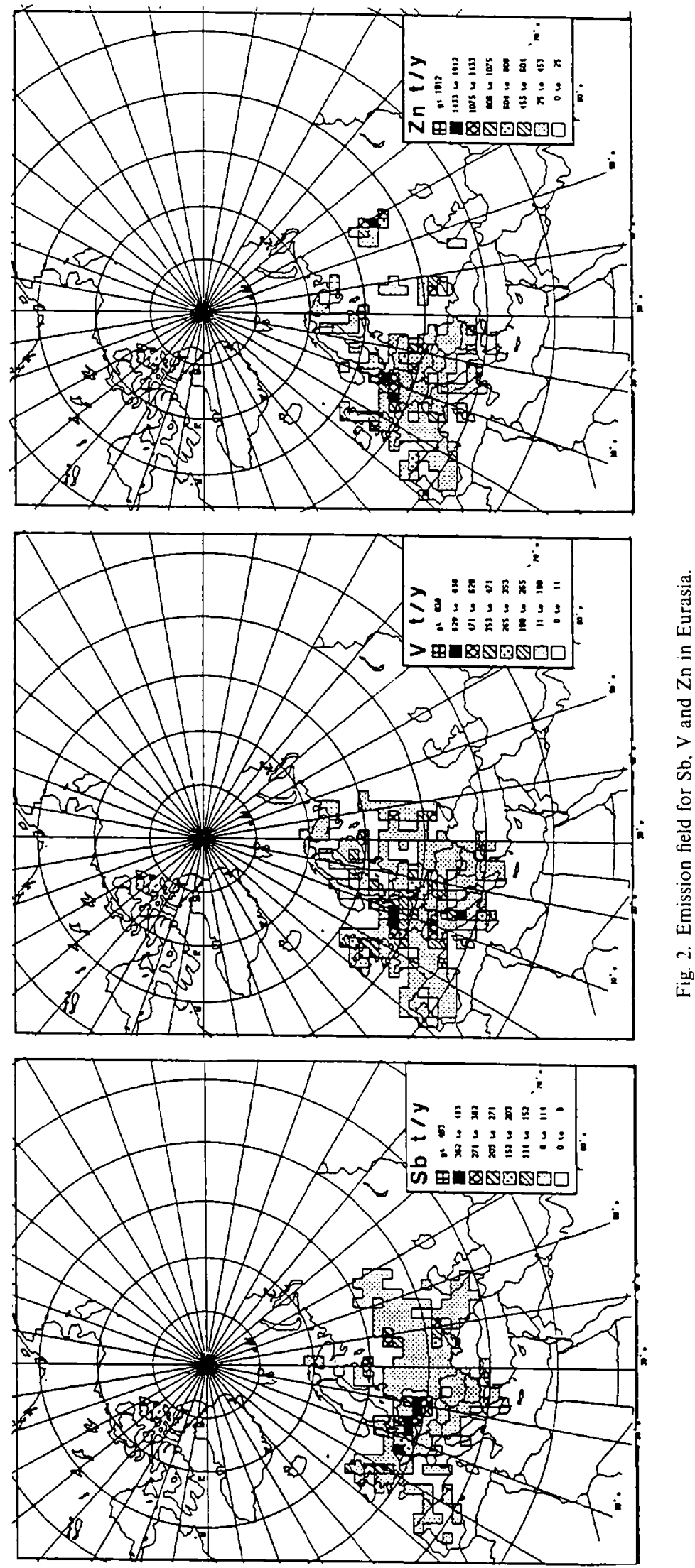


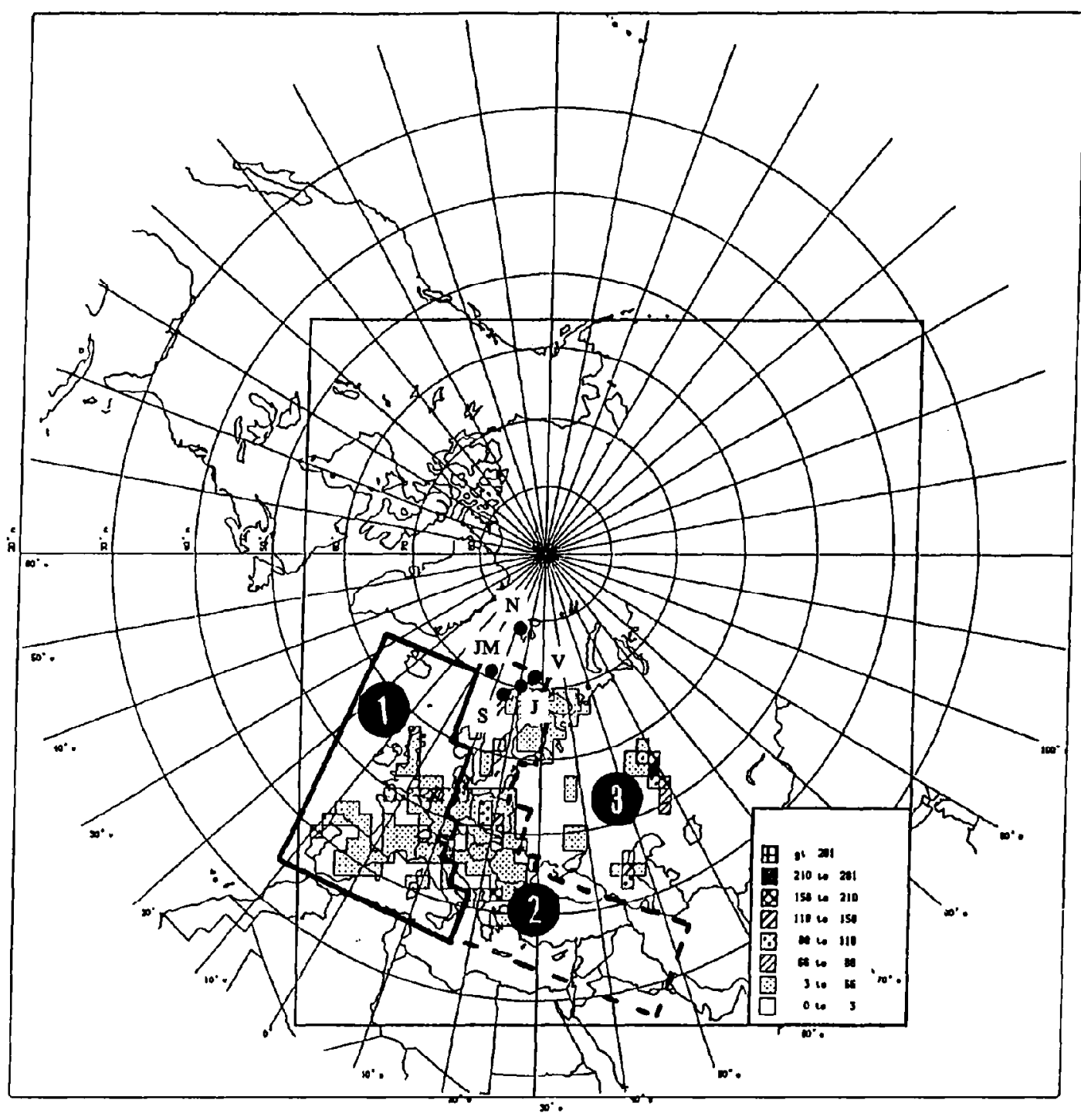

Fig. 3. Emission field for As showing source region boundaries and the location of air monitoring stations providing observations used in the work: 1 --W. Europe; 2 -E. Europe; 3-former Soviet Union. J-Jergul; JM-Jan Mayen; N-Ny Alesund; S-Skrova; V-Vardo.

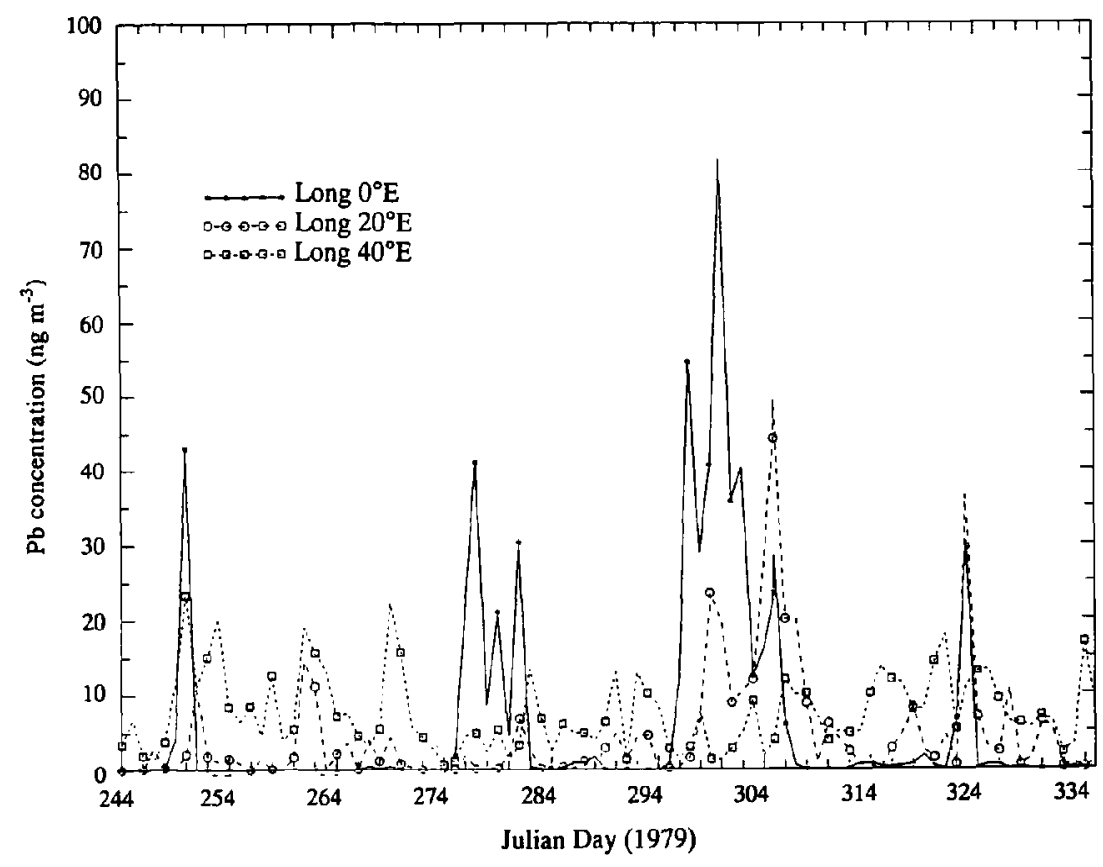

AE 28:8-N Fig. 4. Daily model-predicted lead concentrations at longitudes $0^{\circ}, 20^{\circ} \mathrm{E}$ and $40^{\circ} \mathrm{E}$ on the Arctic Circle for September-November 1979. 


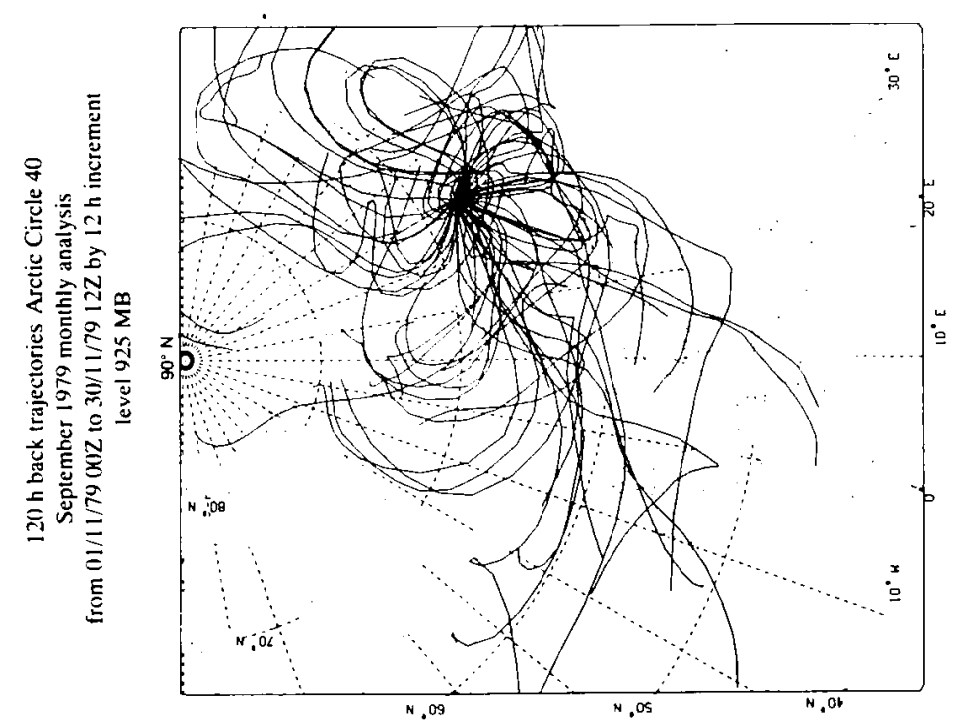

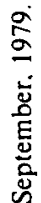
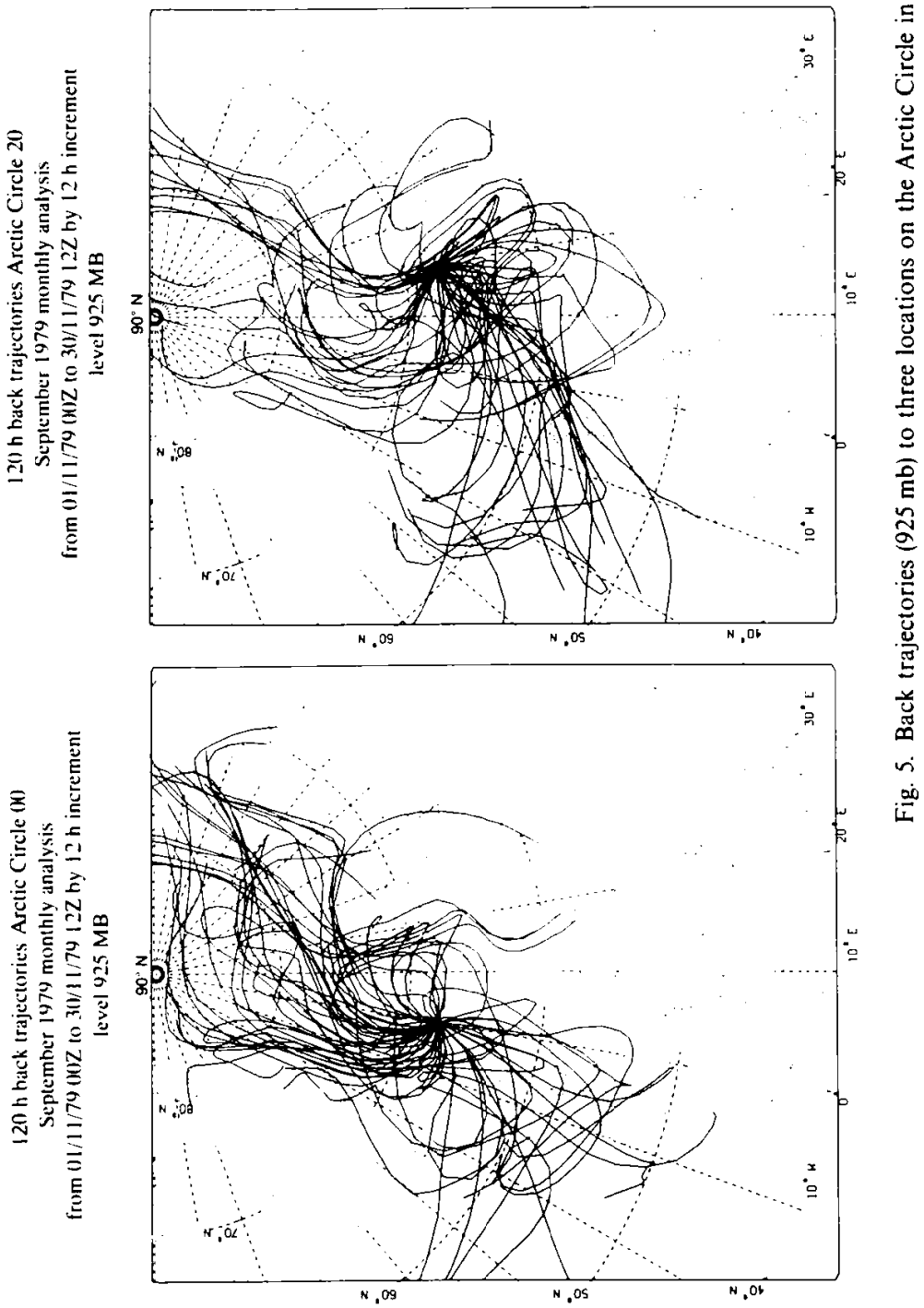


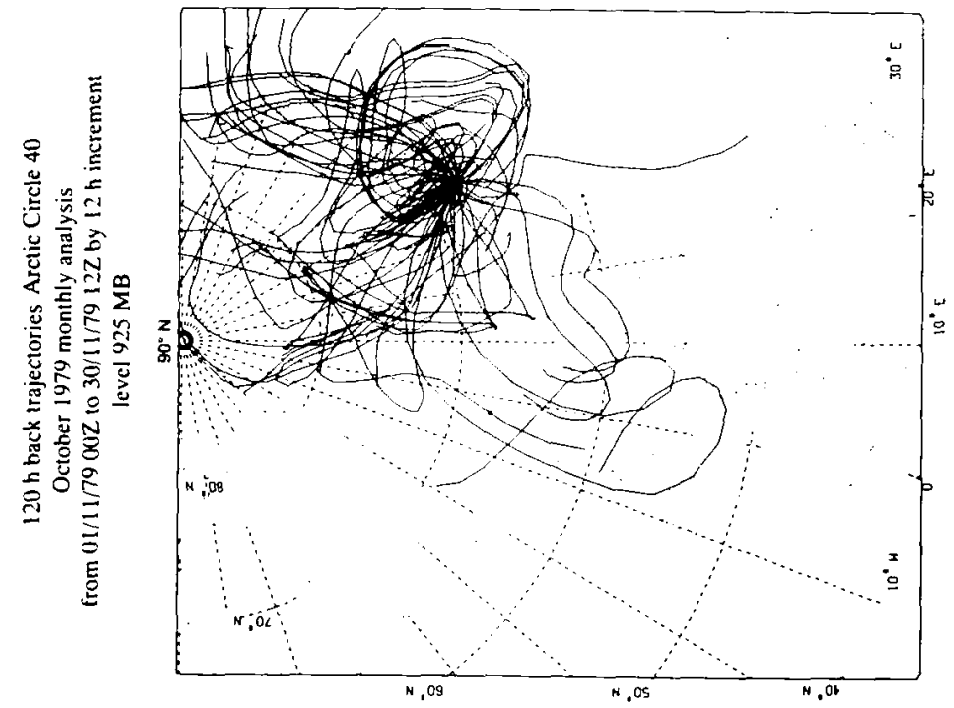

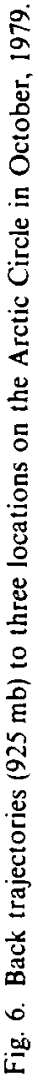




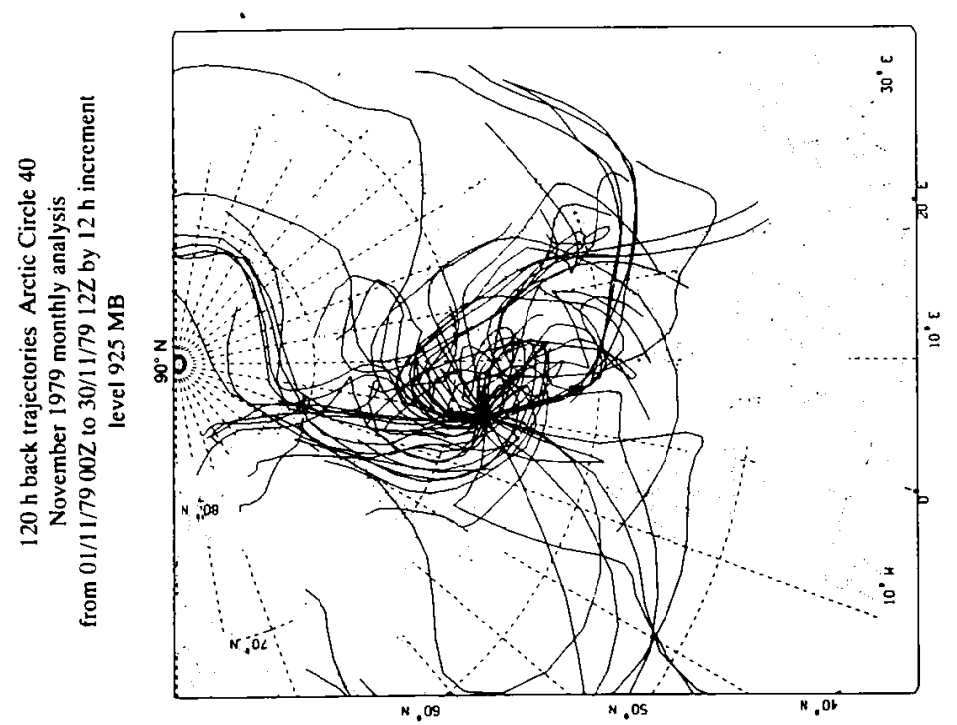

$\frac{9}{5}$
$\frac{5}{8}$
$\frac{8}{0}$
$\frac{1}{2}$
$z$
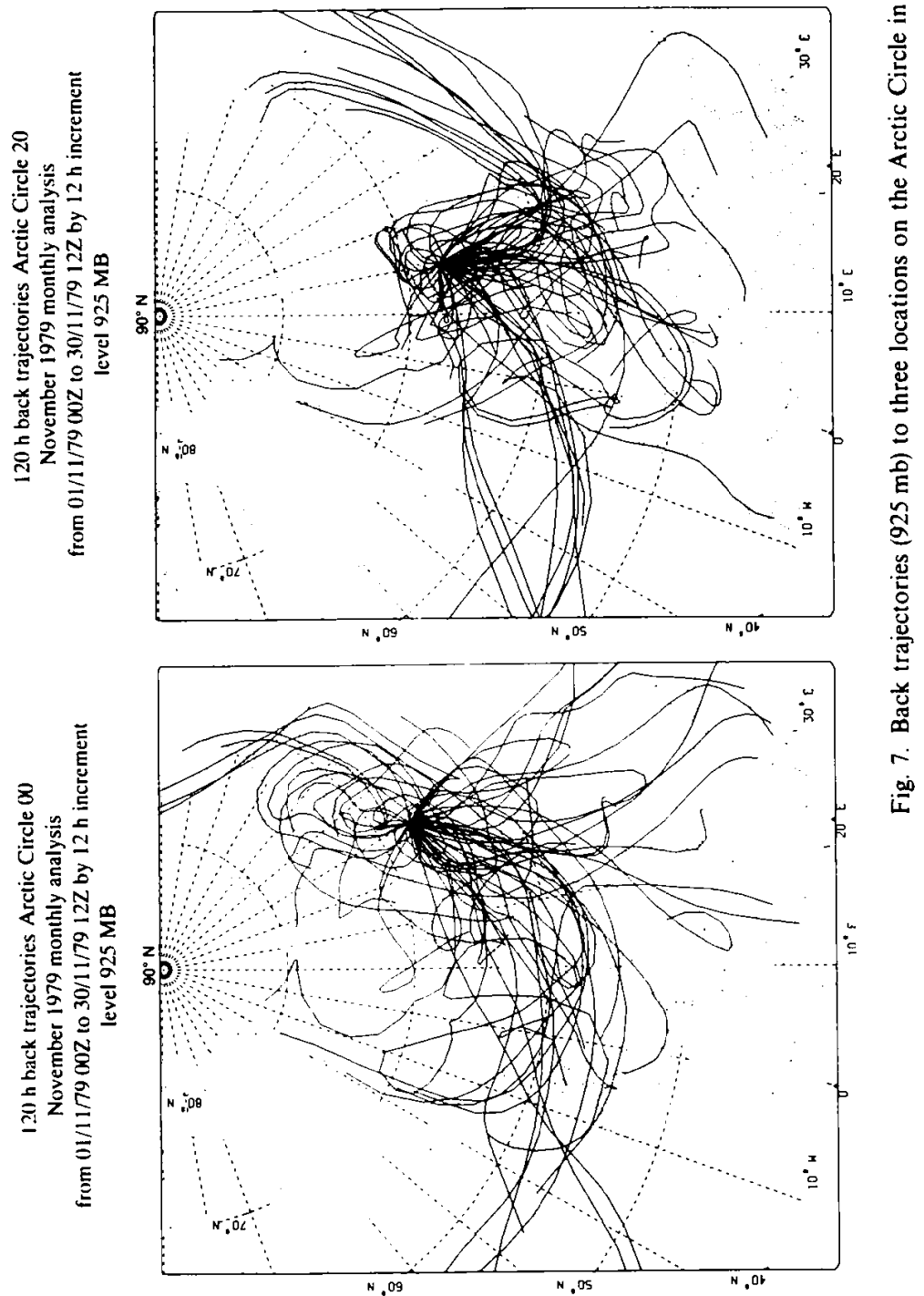


\section{KPA HEIGHTS \\ 01 OCT 78 TO 31 OCT 78 \\ 31-DAY MEAN}

\section{OBSERVED}

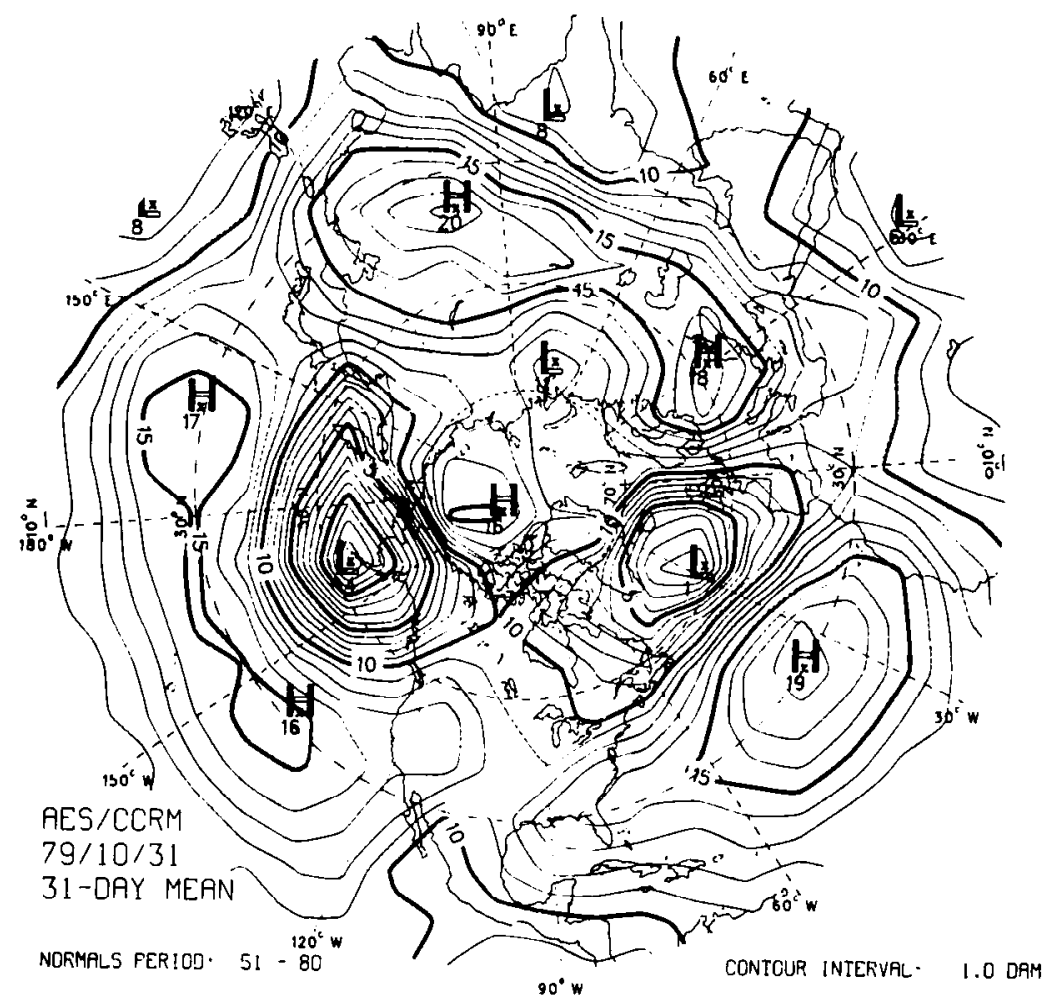

Fig. 8. Height contour (100 kPa) for October, 1979.

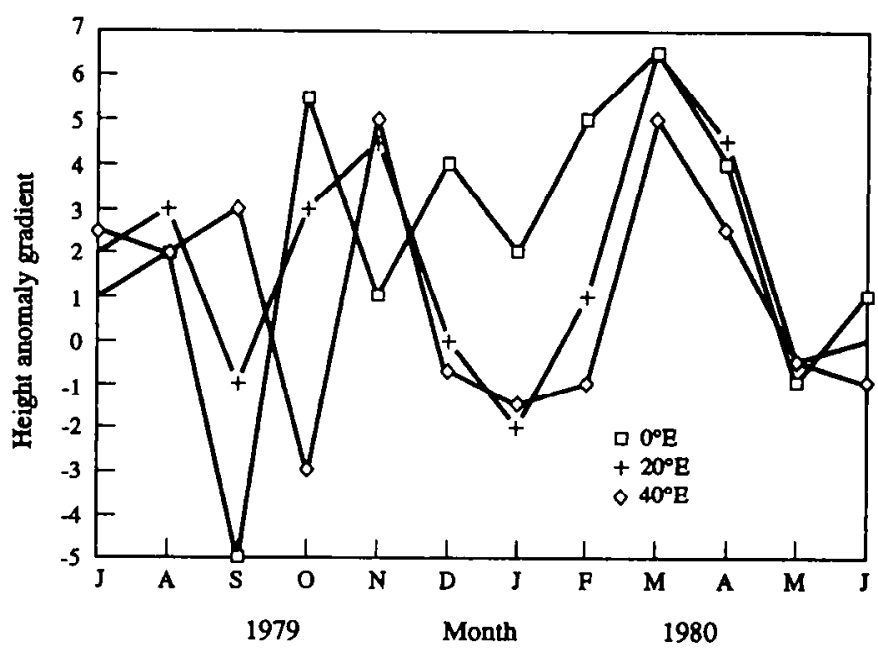

Fig. 9. Height anomaly gradients at longitudes $0^{\circ}, 20^{\circ} \mathrm{E}$ and $40^{\circ} \mathrm{E}$ on the Arctic Circle by month.

in choosing the parameter values used here. The dry deposition velocities chosen for this model were similar to those utilized by Pacyna et al. (1985).

An analysis was performed to determine the sensitivity of the model estimates to input parameters such as dry deposition and wet scavenging ratios. These tests (see Table 2) indicate that halving or doubling both parameters will lead to about a $40 \%$ change from the base case estimate of trace metal concentrations that reached Jergul in northern Norway. 
Table 1. A comparison of deposition velocities and wet scavenging ratios of selected trace metals from the literature with those used in the chemical transport model base case

\begin{tabular}{|c|c|c|c|c|c|}
\hline \multirow[b]{2}{*}{ Element } & \multicolumn{2}{|c|}{ Literature } & \multirow[b]{2}{*}{ Reference } & \multicolumn{2}{|c|}{ This work } \\
\hline & $\begin{array}{c}V_{\mathrm{d}} \\
\left(\mathrm{cm} \mathrm{s}^{-1}\right)\end{array}$ & $\begin{array}{l}W \times 10^{-5} \\
\text { Vol. basis }\end{array}$ & & $\begin{array}{c}V_{d} \\
\left(\mathrm{~cm} \mathrm{~s}^{-1}\right)\end{array}$ & $\begin{array}{l}W \times 10^{-5} \\
\text { Vol. basis }\end{array}$ \\
\hline As & $0.2-1.2$ & $0.9-2.2$ & $b-e, g$ & 0.2 & 3.75 \\
\hline $\mathrm{Cd}$ & $0.1-1.0$ & $1.0-4.2$ & c. e. $f^{-}$ & 0.15 & 3.25 \\
\hline $\mathrm{Pb}$ & $0.2-0.6$ & $0.63-3.6$ & $a-c$, e. $f$ & 0.2 & 5.0 \\
\hline Sb & $0.2-0.8$ & 1.6 & b, e, f, g & 0.15 & 3.25 \\
\hline V & $0.2-1.4$ & $0.9-1.6$ & b, e, r,g & 0.4 & 7.5 \\
\hline $\mathrm{Zn}$ & $0.07-1.0$ & $1.1-8.3$ & $\mathrm{a}-\mathrm{c}, \mathrm{e}, \mathrm{g}$ & 0.2 & 3.75 \\
\hline
\end{tabular}

alinn et al. (1978)-data of Gatz.

'Slinn et al. (1978) - data of Cawse and Harwell.

'McMahon and Denison (1979).

${ }^{d}$ Lindberg (1982).

'Milford and Davidson (1985)

${ }^{\mathrm{I}}$ Davidson (1980).

8 Pacyna et al. (1989).

Table 2. Results of model sensitivity runs for lead concentrations predicted for Jergul

\begin{tabular}{|c|c|c|c|c|c|}
\hline Month & $\begin{array}{c}\text { Base case } \\
\text { conc. } \\
\left(\mathrm{ng} \mathrm{m}^{-3}\right)\end{array}$ & $\begin{array}{l}\text { Ratio of cons } \\
\qquad\left(2 V_{\mathrm{d}}, 2 W\right)\end{array}$ & $\begin{array}{l}\text { for case shown } \\
\left(0.5 l_{\mathrm{d}}^{\prime}, 0.5 W\right)\end{array}$ & $\left(V_{\mathrm{d}}, 0.5 \mathrm{~W}\right)$ & $\left(V_{d}^{\prime} \cdot 0.25 W\right)$ \\
\hline March & 6.7 & 0.6 & 1.5 & 1.2 & 1.4 \\
\hline April & 2.5 & 0.6 & 1.5 & 1.3 & 1.4 \\
\hline May & 26 & 0.7 & 1.3 & 1.1 & 1.2 \\
\hline June & 3.1 & 0.6 & 1.5 & 1.3 & 1.6 \\
\hline July & 2.5 & 0.8 & 1.2 & 1.1 & 1.2 \\
\hline August & 3.5 & 0.6 & 1.5 & 1.3 & 1.6 \\
\hline September & 2.1 & 0.5 & 1.5 & 1.4 & 1.7 \\
\hline
\end{tabular}

* $\left(0.5 V_{d}, 0.5 W\right)$ refers to half of base case values of both dry deposition velocity and wet scavenging ratio, etc.

Also, an assessment was made of whether the distribution of the fluxes originating from the different source regions in Eurasia was biased by the choice of model parameterization (see below). This was found not to be the case. The ratio of the flux originating from the former Soviet Union to the flux from western Europe for the base case values of $V_{\mathrm{d}}$ and $W$ was 1.01. The ratio of the fluxes for case where the values were double the base case values and half the base case values were 1.07 and 0.96 , respectively.

\section{RESULTS AND DISCUSSION}

\section{Model predictions vs observations}

In the previous paper on sulfur fluxes into the Arctic (Barrie et al., 1989), continuous measurements of airborne concentrations were available for the entire study period at two northern Norwegian locations near the Arctic Circle with which to check model predictions. For metals, however, continuous measurements were not made but are available from a number of separate studies between 1977 and 1984. These data are summarized and compared with model predictions in Table 3. Model-estimated concentrations agreed with observed to within a factor of 2-3. Considering the limited number of observations, this agreement is quite reasonable and within the range suggested by the sensitivity analysis.

Dependence of metal fluxes on longitude and Eurasian source reyion

The main pathways into the Arctic for July 1979 June 1980 are shown in Fig. 10. The percentages of emitted trace metals reaching the Arctic from Eurasia (see Table 4) range between $25-100 \%$ of the value calculated for sulfur as reported by Barrie et al. (1989). For the case when the spatial distribution of sulfur and trace metal emissions are similar, this would mean that the removal processes (wet scavenging and dry deposition) appeared less effective at removing sulfur than the metal. Since sulfur and the trace metals $(\mathrm{Pb}$, $\mathrm{Sb}, \mathrm{V}$ and $\mathrm{Zn}$ ) are usually products of fuel combustion processes which are often correlated in space, the spatial distribution of their emissions should be similar. However. not all metals studied enter into the Arctic at the same longitude. The highest fluxes of antimony, lead, vanadium, zinc (see Fig. 10) and sulfur 
Table 3. Comparison of model predictions for months in the period July 1979-June 1980 with observed concentrations of lead measured at sites located close to the Arctic Circle

\begin{tabular}{|c|c|c|c|c|}
\hline Location & Period & $\begin{array}{l}\text { Concentration } \\
\text { observed }\end{array}$ & Model & Reference \\
\hline Ny-Alesund & $\begin{array}{l}\text { March } 83 / 84 \\
\text { August } 77 / 79 \\
82 / 83 \\
\text { September } \\
77 / 79,82 / 83\end{array}$ & $\begin{array}{l}7.3 \pm 4.6 \\
1.1 \pm 0.9 \\
0.7 \pm 0.4\end{array}$ & $\begin{array}{l}2.6 \\
0.3 \\
0.7\end{array}$ & $\begin{array}{l}a, b, c, d \\
b, c \\
b, c\end{array}$ \\
\hline Jergul & $\begin{array}{l}\text { March } 83 / 84 \\
\text { June } 84 \\
\text { July } 84 \\
\text { September } 82 / 83\end{array}$ & $\begin{array}{l}4.6 \pm 1.6 \\
0.9 \\
1.7 \\
5.0 \pm 3.3\end{array}$ & $\begin{array}{l}6.7 \\
3.1 \\
2.5 \\
2.1\end{array}$ & $\begin{array}{l}\mathrm{b} \\
\mathrm{b} \\
\mathrm{b} \\
\mathrm{b}, \mathrm{c}\end{array}$ \\
\hline Skrova & $\begin{array}{l}\text { March } 83 / 84 \\
\text { June } 84 \\
\text { July } 84 \\
\text { August } 82 / 83 \\
\text { September } 82 / 83\end{array}$ & $\begin{array}{l}3.3 \pm 0.3 \\
0.4 \\
4.6 \\
0.9 \pm 0.5 \\
5.6 \pm 0.5\end{array}$ & $\begin{array}{l}7.8 \\
3.0 \\
1.7 \\
3.5 \\
1.6\end{array}$ & $\begin{array}{l}b, d \\
b \\
b \\
b, c \\
b, c\end{array}$ \\
\hline Jan Mayen & $\begin{array}{l}\text { March } 83 / 84 \\
\text { June } 84 \\
\text { July } 84 \\
\text { August } 82 / 83 \\
\text { September } 82 / 83\end{array}$ & $\begin{array}{l}2.3 \pm 0.8 \\
0.8 \\
0.3 \\
0.3 \pm 0.2 \\
0.2 \pm 0.2\end{array}$ & $\begin{array}{l}1.1 \\
0.5 \\
0.2 \\
0.7 \\
0.02\end{array}$ & $\begin{array}{l}b, d \\
b \\
b \\
b, c \\
b, c\end{array}$ \\
\hline
\end{tabular}

Table 4. A comparison of model-predicted total annual trace metal fluxes to the Arctic for $1979 / 80$ with emissions

\begin{tabular}{|c|c|c|c|c|}
\hline Metal & Arctic flux & $\begin{array}{l}\text { Total emission } \\
\qquad\left(\mathrm{t} \mathrm{yr}^{-1}\right)\end{array}$ & Flux as $\%$ of emission & $\begin{array}{l}\text { Longitude of highest flux } \\
\qquad\left(\mathrm{yr}^{-1}\right)\end{array}$ \\
\hline Arsenic & 285.3 & 4797.4 & 5.93 & $20 \mathrm{E}(115 \mathrm{t})$ \\
\hline Cadmium & 47.3 & 1139.9 & 4.15 & $20 \mathrm{E}(15 \mathrm{t})$ \\
\hline Lead & 2401.1 & $80,838.9$ & 2.97 & $0 \mathrm{E}(950 \mathrm{t})$ \\
\hline Vanadium & 473.5 & $27,374.4$ & 1.73 & $0 \mathrm{E}(210 \mathrm{t})$ \\
\hline Antimony & 4.1 & 123.2 & 3.35 & $0 \mathrm{E}(1.7 \mathrm{t})$ \\
\hline Zinc & 1346.3 & $43,270.2$ & 3.11 & $O E(550 t)$ \\
\hline Sulfur* & $2150+$ & $32,000+$ & 6.72 & $O E(560 t)$ \\
\hline
\end{tabular}

* From Barrie et al. (1989).

+ Unit is kilotonnes.

occur at longitude zero while those of arsenic and cadmium occur at about $20^{\circ} \mathrm{E}$. This appears consistent with the locations of the largest sources in Europe. For instance, more large emission sources of $\mathrm{Pb}, \mathrm{Sb}, \mathrm{V}$ and $\mathrm{Zn}$ are located to the north of latitude $50^{\circ} \mathrm{N}$ (taken, for the sake of this discussion, as demarcating the endpoints for a 5-d back trajectory originating from the Arctic Circle) between longitudes $10^{\circ} \mathrm{W}$ and $10^{\circ} \mathrm{E}$ than is the case for As and $\mathrm{Cd}$ for which the large sources are located to the east of longitude $10^{\circ} \mathrm{E}$ (see Figs 1 and 2). The relative fractions of emitted metals that reach the Arctic suggest that lead, vanadium, zinc and antimony are removed at least twice as efficiently as sulfur. Those trace metals are formed mainly in high temperature processes and exist more in the fine size fractions, just like sulfate particles. The more efficient removal during long range transport may suggest a greater contribution by wet scavenging to the overall removal for the metals compared to sulfur. It should be noted that in the source grid no loss was assumed for sulfur compared with $11 \%$ for the trace metals.

High fluxes occurred between longitudes $20^{\circ} \mathrm{E}$ and $60 \mathrm{E}$ for arsenic and cadmium. In terms of sources, eastern Europe appears to be the highest contributor to the total fluxes of all the elements except lead and sulfur for which the highest contributor was the former Soviet Union (which was followed very closely by western Europe) (see Table 5). This disagrees with the results of Lowenthal and Rahn (1985) and other estimates based on their proposed source signatures (Maenhaut et al., 1989). Lowenthal and Rahn reported that $90,80,75$ and $73 \%$ of $\mathrm{As}, \mathrm{V}, \mathrm{Zn}$ and $\mathrm{Sb}$, respectively, comes from formerly central U.S.S.R. (i.e. Norilsk) as deduced from elemental tracers. It suggests 


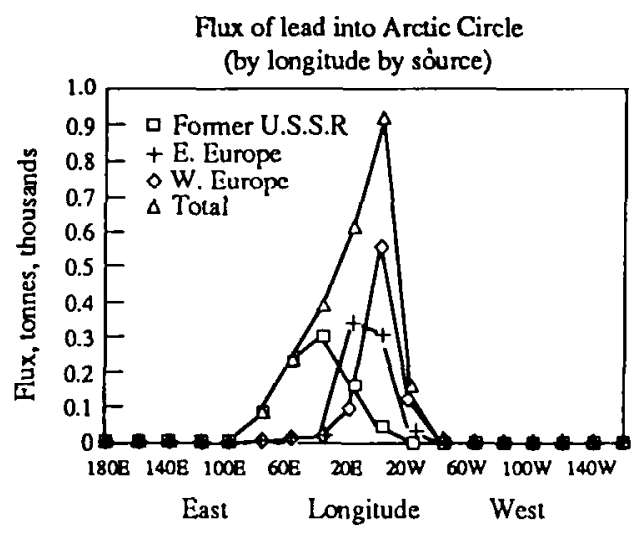

Fux of vanadium into Arctic Circle (by longitude by source)

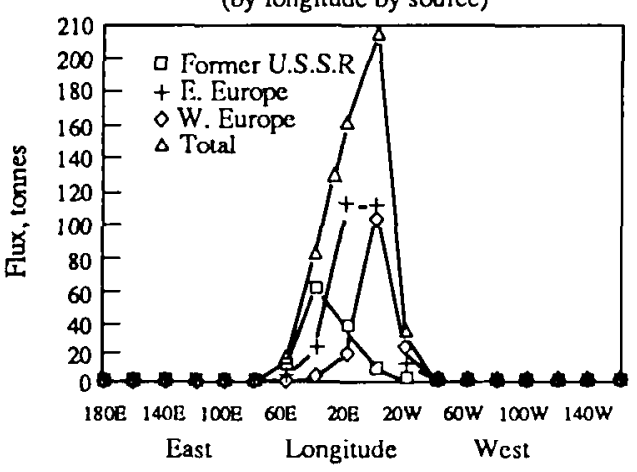

Fux of antimony into Arctic Circle (by longitude by source)

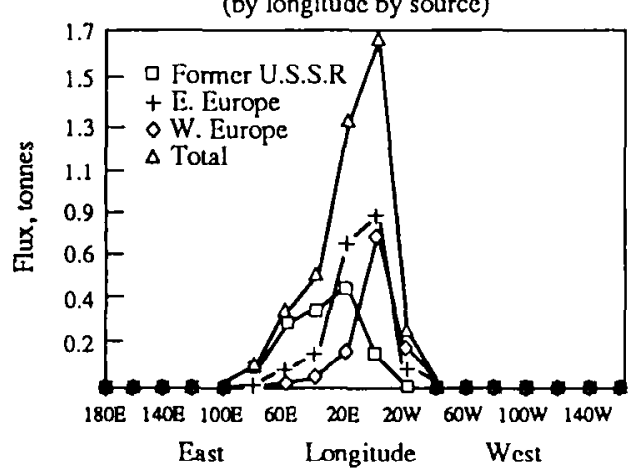

Flux of arsenic into Arctic Circle (by longitude by source)

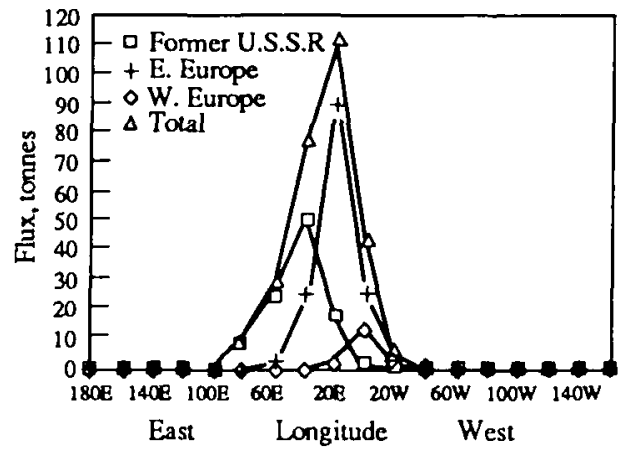

Flux of zinc into Arctic Circle (by longitude by source)

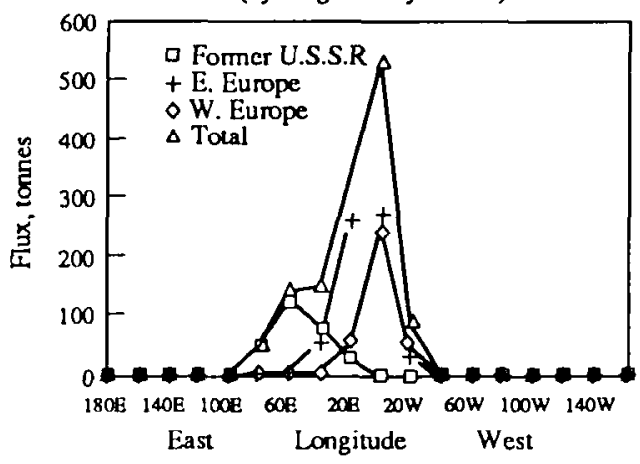

Flux of cadmium inw Arctic Circle (by longitude by source)

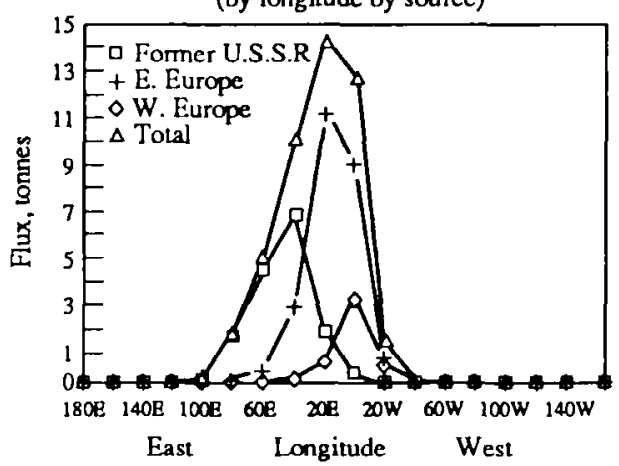

Fig. 10. Flux by longitude by source of July 1979-June 1980.

that either Barrow experiences air masses with sources different from those of the rest of the Arctic or that the assumptions that different regions in Eurasia have uniquely different aerosol elemental signatures is not entirely correct.

\section{Dependence of metal fluxes on month and altitude}

Total fluxes entering the Arctic Circle by month and altitude are plotted in Fig. 11. As with sulfur, most of the trace element flux takes place in the lower troposphere (below $1 \mathrm{~km}$ ). However, in spring, more input into the Arctic troposphere takes place between 1 and
$3 \mathrm{~km}$ altitudes than is found in winter. In terms of annual variation of the fluxes of the metals into the Arctic, the model simulated the spring maximum and a summer minimum which all previous measurements seem to indicate (e.g. see the March data in Table 3). In addition, a peak was also found in October for all of the metals. The October peak was quite unexpected and warranted further investigation. It was found (see Fig. 12) to be due to an influx occurring at longitude $0^{\circ}$ on the Arctic circle and originating mainly from eastern Europe. Both September and November $\mathrm{Pb}$ fluxes differed from the October flux in magnitude as 
Table 5. A comparison of the fraction ( $\%$ ) of model-predicted total flux of metals to the Arctic from Eurasian source regions from July 1979 to June 1980 as a function of source region with Lowenthal and Rahn's estimate using a multi-elemental tracer technique

\begin{tabular}{lcccc}
\hline & \multicolumn{3}{c}{ Percentage contribution to overall flux } \\
\cline { 3 - 5 } & & & \multicolumn{2}{c}{ Former Soviet Union } \\
\cline { 3 - 5 } & & & Lowenthal et al. \\
Element & West Europe & East Europe & This work & $(1985)$ \\
\hline As & 7.4 & 54.1 & 38.5 & 90 \\
$\mathrm{Cd}$ & 11.6 & 53.5 & 34.9 & \\
$\mathrm{~Pb}$ & 33.7 & 30.0 & 34.0 & 73 \\
$\mathrm{Sb}$ & 26.6 & 42.1 & 31.0 & 80 \\
$\mathrm{~V}$ & 27.7 & 50.3 & 21.4 & 75 \\
$\mathrm{Zn}$ & 28.0 & 48.6 & 23.2 & \\
S* & 26.7 & 28.7 & 44.7 & \\
\hline
\end{tabular}

* From Barrie el al. (1989).

well as the longitude of the maximum flux on the Arctic circle.

The plots of daily concentrations at three locations on the Arctic Circle (namely, longitudes $0 \% 20 \mathrm{E}$ and $40^{\circ} \mathrm{E}$ ) for September until November (see Fig. 4) indicated that two major episodes (occurring between days 274 and 282 and between days 295 and 306) were responsible for the high trace metal concentrations in October. The 5-d back trajectories at the 925, 850 and $700 \mathrm{mb}$ levels were plotted for the period. Those trajectories (not shown) indicated that winds were southerly in response to high pressure systems centered in eastern Europe. The winds were from the pollutant source regions in Poland, northern Czechoslovakia, former F.R Germany, former German Democratic Republic, former western Soviet Union, Norway, Sweden and the United Kingdom, in a narrow band which funnelled to longitude zero on the Arctic Circle. It is likely that the pollutants transported to the Arctic during the first episode also caused an unexpected high concentration of lead observed at the Canadian aerosol measurement station in Mould Bay a week later. In contrast, trajectories to longitude $20 \mathrm{E}$ and $40 \mathrm{E}$ on the Arctic Circle originated and moved predominantly either over oceans or polar regions. The latter case was also true for the trajectories to all three locations in the period between days 282 and 295 . The trajectories for October (Fig. 6) show more consistent southerly flow (at all three pressure levels considered) than those for September and November (See Figs 5 and 7). This is also seen in the mean monthly $100 \mathrm{kPa}$ height contour chart for October, 1979 (Fig. 8) which also indicates southerly flows were predominant along 0 longitude at the Arctic Circle during the month, while the height anomalies plot (not shown) indicated that there was a large departure from the $30-y r$ normals of the east to west pressure gradient along 0 longitude at the Arctic Circle in that month. These synoptic conditions could lead to high injections of pollutants into the Arctic in October such as the model results indicated.
The gradient of height anomalies in the Arctic around longitude zero (defined as the difference in height anomalies in decameters between longitude $30^{\circ} \mathrm{E}$ and $30^{\circ} \mathrm{W}$ ) was calculated. A high positive value of the gradient indicates abnormally high northward flow at longitude zero on the Arctic Circle. The results are shown in Fig. 9. Height anomaly gradients, at longitude $0^{\circ}$, higher than 5 decameters over the $60^{\circ}$ of longitude measured at the Arctic Circle occurred only in October and in March. Also included are height anomaly gradients calculated for $20^{\circ} \mathrm{E}$ and $40^{\circ} \mathrm{E}$. It is apparent that above-average northward flow compared to 30-yr means occurred at all longitudes in March and April, only at $0^{\circ}$ and $20^{\circ} \mathrm{E}$ in October and only at 0 in December, January and February. These results suggest that the case study year $1979 / 80$ may be only slightly unrepresentative in that flow into the Arctic at longitude 0 was stronger than normal for part of the high input periods (January-May and October).

\section{The fraction of pollutant inputs that are deposited in the} Arctic

Estimates of the depositional flux of trace metals in the Arctic were performed for a few elements, $\mathrm{Cd}, \mathrm{Pb}$, $\mathrm{V}$ and $\mathrm{S}$, using two methods shown in Table 6 . The first approach (labeled Method $A$ in Table 6) estimated the net deposition from measurements of trace element concentrations in Arctic snowfall by Mart (1983) and climatological precipitation amounts $(P)$ in the Arctic for the warm and cold periods from June to October, and November to May. The precipitation amount was estimated to be 78 and $41 \mathrm{~mm}(1 \mathrm{~mm}$ $=1 /$ of water per square meter), respectively. The deposition flux of $\mathrm{Cd}$ and $\mathrm{Pb}$ for the warm period is 0.4 and $13 \mathrm{ng} \mathrm{kg}^{-1}$, and for the more polluted cold period 7 and $275 \mathrm{ng} \mathrm{kg}^{-1}$. These are based on only a few snowfalls.

The second technique (Method B in Table 6) simply used the deposition estimates for non-crustal $\mathrm{V}, \mathrm{Cd}$ and $\mathrm{Pb}$ to the Arctic Ocean (area $1.2 \times 10^{13} \mathrm{~m}^{2}$ ) made 
Flux of lead into Arctic Circle (by month and aluitude)

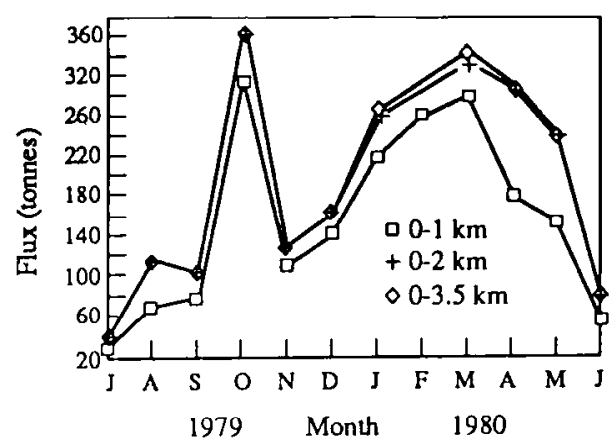

Flux of vanadium into Arctic Circle (by month and altitude)

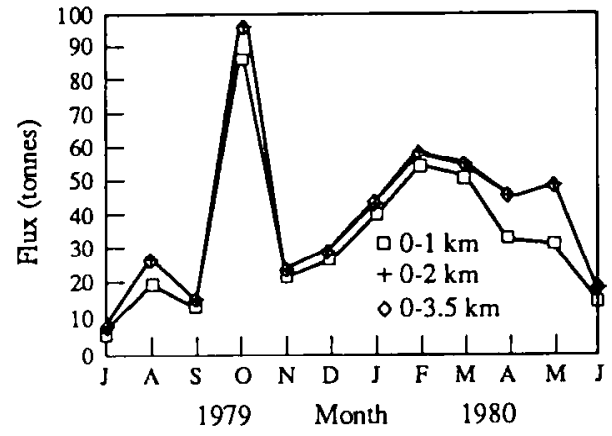

Flux of antimony into Arctic Circle (by month and altitude)

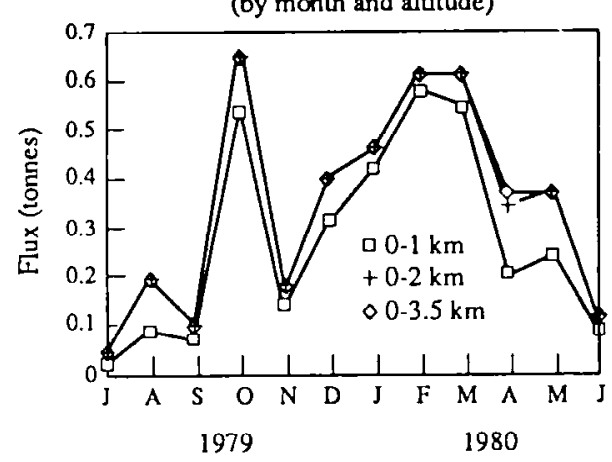

Flux of arsenic into Arctic Circle (by month and altitude)

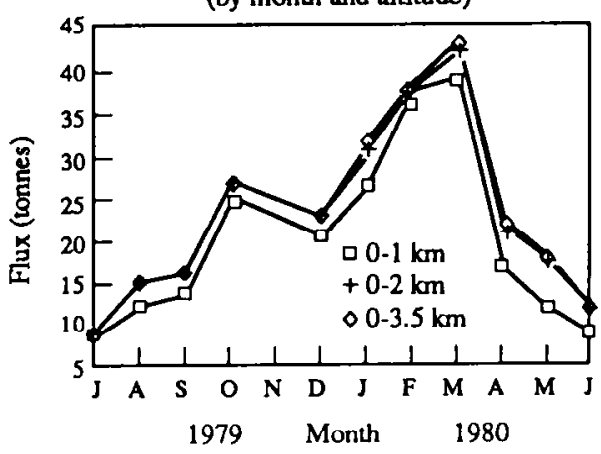

Flux of zinc into Arcuic Circle (by month and altitude)

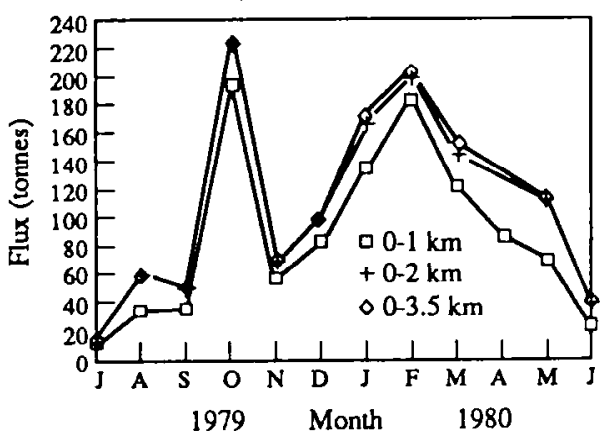

Flux of cadmium into Arctic Circle (by month and altitude)

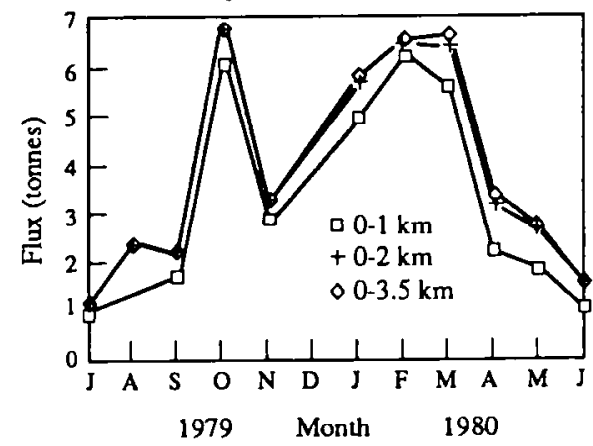

Fig. 11. Flux by month and altitude.

Table 6. A comparison of Arctic flux of trace elements with their estimated deposition

\begin{tabular}{|c|c|c|c|c|c|c|}
\hline \multirow[b]{3}{*}{ Element } & \multirow{3}{*}{$\begin{array}{l}\text { Arctic flux } \\
\left(t \mathrm{yr}^{-1}\right)\end{array}$} & \multirow{3}{*}{$\begin{array}{l}\text { Estimated European emissions } \\
\qquad\left({\left.\mathrm{t} \mathrm{yr}^{-1}\right)}^{-1}\right.\end{array}$} & \multicolumn{4}{|c|}{ Estimated deposition to the Arctic } \\
\hline & & & \multicolumn{2}{|c|}{ Method $A^{*}$} & \multicolumn{2}{|c|}{ Method B† } \\
\hline & & & $\left(t y^{-1}\right)$ & $\%$ & $\left(t \mathrm{yr}^{-1}\right)$ & $\%$ \\
\hline $\mathrm{Cd}$ & 47.3 & 1139.9 & 6.7 & 14 & 47.8 & 101 \\
\hline $\mathrm{Pb}$ & 2401.1 & $80,838.9$ & 258 & 11 & 1331 & 55 \\
\hline $\mathrm{V}$ & 473.5 & $27,374.4$ & & & 102 & 22 \\
\hline Sł & $2150 \S$ & $32,000 \$$ & $248,000 \|$ & 12 & & \\
\hline
\end{tabular}

* Based on snow chemistry measurements of Mart (1983).

† Based on estimates by Rahn (1981b).

$\ddagger$ From Barrie el al. (1989).

$\S$ Unit is kilotonnes.

$\|$ Based on $\left[\mathrm{SO}_{4}^{2-}\right]=16 \mu \mathrm{eq} t^{-1} \mathrm{SO}_{4}^{2-}$ and winter precipitation of $41 \mathrm{~mm}$. 

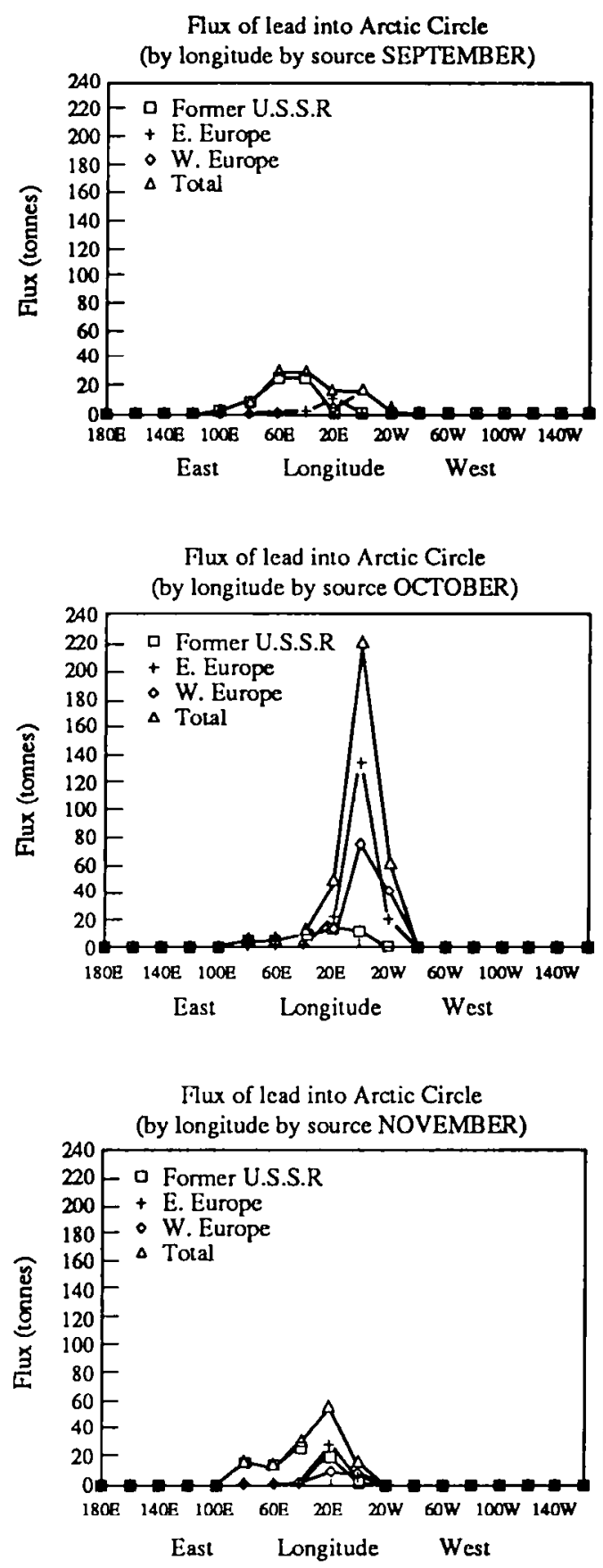

Fig. 12. Flux of $\mathrm{Pb}$ by longitude by source for September-November, 1979.

by Rahn (1981b) to yield an estimate for the whole Arctic cap above $66.5^{\circ} \mathrm{N}$ (area $2.1 \times 10^{13} \mathrm{~m}^{2}$ ). Rahn's mean values from his Table 2 were used in this analysis. They were based on three different approaches: (1) applying a total deposition to observed aerosol concentrations, (2) estimating from North Slope Alaska snow composition during winter from Weiss et al. (1978) with $P=104 \mathrm{~mm}$, and (3) estimating from southern Greenland snow concentration, measured by Herron et al. (1977) and Boutron (1978) with a $P$ of
$350 \mathrm{~mm}$. Approach (1) is highly uncertain because the total deposition velocity is not well known. Approach (2) is an upper estimate of annual deposition because winter snow composition was used and is not likely to be representative of the composition of summer precipitation (see the observations of Mart, above). Approach (3) is not very representative of the lower Arctic troposphere, since the southern Greenland icecap is at $3 \mathrm{~km}$ altitude, and generally has lower concentrations of metals in snow and more precipitation. It is also likely that the $\mathrm{Pb}$ concentration measurements used in this work are high due to contamination. Thus, it is expected that Method $A$ is more realistic than Method B.

With these limitations in mind, the results from Method A in Table 6 show that between 11 and $14 \%$ of trace metals entering the Arctic are deposited there. Method B gave much higher results as expected and are probably unrealistic. Clearly, more routine observations of Arctic precipitation and determinations of its composition are needed. The above observations do, however, demonstrate that substantial amounts of trace elements can be transported to the Arctic and deposited there.

\section{CONCLUSIONS}

The application of a chemical transport model using observed winds in the Northern Hemisphere and estimated emissions of trace elements in Eurasia for calculating inputs to the Arctic has yielded new quantitative insights into human influence on the polar regions.

The total annual flux of antimony, arsenic, cadmium, lead, zinc and vanadium into the Arctic from Eurasia were 4, 285, 47, 2400, 1350 and 474 tonnes, respectively. These fluxes represent $3.4,6.0,4.2$, $3.0,3.1$ and $1.7 \%$ of the source emissions, respectively. In contrast, the corresponding flux of sulfur was 2.2 million tonnes or $6.7 \%$ of the total emissions.

The model also showed that in addition to a late winter maximum input to the Arctic, a peak was also shown in October. Back trajectory analysis for October 1979 indicated two episodes with southerly winds which passed over Eurasia to the Arctic around longitude zero and confirms model-predicted high pollutants input to the Arctic for that month.

Comparison of the model-predicted trace metal concentrations in 1979/80 with limited observations from other years at sampling stations close to the Arctic Circle (namely $\mathrm{Ny}$ Alesund in Spitsbergen, Jergul, Skrova and Jan Mayen) showed that they were within a factor of 2-3.

For lead, there was a nearly equal Arctic input from each of the three source regions investigated (namely western Europe, eastern Europe and the former Soviet Union). But for $\mathrm{As}, \mathrm{Cd}, \mathrm{Sb}, \mathrm{V}$ and $\mathrm{Zn}$, the highest Arctic input originated from eastern Europe. In contrast, the highest input of sulfur to the Arctic 
originated from the former Soviet Union (Barrie and Schemenauer, 1989). These findings contradicted those reported by Lowenthal and Rahn (1985) who for the same time period attributed $75-90 \%$ of these trace elements in aerosols at Barrow, Alaska, to sources in the former Soviet Union.

Not all trace elements enter into the Arctic at the same longitude. The highest fluxes of antimony, lead, vanadium, zinc and sulfur occur at longitude zero while those of arsenic and cadmium occur at $20^{\circ} \mathrm{E}$. Trace metals such as $\mathrm{Pb}, \mathrm{Sb}, \mathrm{V}$ and $\mathrm{Zn}$ are removed by wet scavenging and dry deposition processes en route the Arctic at least twice as efficiently as sulfur.

An estimated $11-14 \%$ of the trace metals predicted to be entering the Arctic by the model are deposited there. More measurements of metals in Arctic precipitation are necessary.

Acknowledgement-The authors thank A. Sirois, Bill Sukloff and B. Pabla for the use of their programs for drafting the maps. One of us (FAA) received support under the Canadian Government Visiting Fellowship program.

\section{REFERENCES}

Barrie L. A. (1986) Arctic air pollution: a review of current knowledge. Atmospheric Environment 20, 643-663.

Barrie L. A. (1992a) Arctic contaminants: sources, occurrence and pathways. Sci. total Envir. 122, 1-74.

Barrie L. A. (1992b) Scavenging ratios: black magic or a useful scientific tool. In Precipitation Scavenging and Atmospheric-Surface Exchange, Vol. 1 (edited by Schwartz S. E. and Slinn W. G. N.), pp. 403-420. Hemispheric Publishing Co., Washington.

Barrie L. A. and Hoff R. F. (1985) Five years of air chemistry observations in the Canadian Arctic. Atmospheric Environment 19, 1995-2010.

Barrie L. A. and Barrie M. J. (1990) Chemical components of lower troposphere aerosols in the high Arctic: six years of observations. J. atmos. Chem. 11, 211-226.

Barrie L. A. and Schemenauer R. S. (1989) Wet deposition of heavy metals. In Control and Fate of Atmospheric Trace Metals (edited by Pacyna J. M. and Ottar B.), NATO ASI SERIES C, Vol 268, pp. 203-230. Kluwer, Dordrecht.

Barrie L. A., Olson M. P. and Oikawa K. K. (1989) The flux of anthropogenic sulfur into the Arctic from mid-latitudes in 1979/80. Atmospheric Environment 23, 2505-2512.

Boutron C. (1978) Influences des aerosols naturels at anthropogeniques sur la geochemie des neiges polaires. $\mathrm{Ph} . \mathrm{D}$. Thesis, Univ. Scientif. et Medicale de Granoble, $283 \mathrm{pp}$.

Davidson C. I. (1980) In Cadmium in the Environment Part I (edited by Nriagu J.), pp. 115-139. John Wiley, New York.

Davidson C. I., Santhanam S., Fortmann R. C. and Olson M. P. (1985) Atmospheric transport and deposition of trace elements onto the Greenland Ice Sheet. Atmospheric Environment 19, 2065-2082.

Heintzenberg J. (1989) Arctic haze: pollution in polar regions Ambio 18, 50-55.

Herron M. M., Langway C. C. Jr, Weiss H. V. and Cragin J. H. (1977) Atmospheric trace metals and sulphate in the Greenland ice sheet. Geochim. Cosmochim. Acta 41, 915-920.

Hoff R. M., Leaitch W. R., Fellin P. and Barrie L. A. (1983) Mass-size distributions of chemical constituents of the winter Arctic aerosol. J. geophys. Res. 88, 10,947-10,956.

Lindberg S. E. (1982) Factors influencing trace metal. sulph- ate and hydrogen ion concentrations in rain. Atmospheric Environment 16, 1701-1709.

Lowenthal D. H. and Rahn K. A. (1985) Regional sources of pollution aerosol at Barrow Alaska during winter 1979-80 as deduced from elemental tracers. Atmospheric Environment 19, 2011-2024.

Maenhaut W., Cornille P., Pacyna J. M. and Vitols V. (1989) Trace element composition and origin of the atmospheric aerosol in the Norwegian Arctic. Atmospheric Environment 23, 2551-2569.

Mart L. (1983) Seasonal variations of $\mathrm{Cd}, \mathrm{Pb}, \mathrm{Cu}$ and $\mathrm{Ni}$ levels in snow from the eastern Arctic Ocean. Tellus 35B, $131-141$.

McMahon T. A. and Denison P. J. (1979) Empirical atmospheric deposition parameters-a survey. Atmospheric Environment 13, 571-585.

Milford J. B. and Davidson C. I. (1985) The size of particulate trace elements in the atmosphere-a review. J. Air Pollut. Control Ass. 35, 1249-1260.

Olson M. P. and Oikawa K. K. (1989) Interannual variability of transboundary sulfur flux. Atmospheric Environment 23, $333-340$.

Ottar B. (1989) Arctic air pollution: a Norwegian perspective Atmospheric Environment 23, 2501-2512.

Ottar B. and Pacyna J. M. (1984) Sources of Ni, Pb and $\mathrm{Zn}$ during the Arctic episode in March 1983. Geophys. Res. Lett. 11, 441-444.

Pacyna J. M. (1983) Trace element emission from anthropogenic sources in Europe. TR Report 10/82. The Norwegian Institute for Air Research, Lillestrom, Norway.

Pacyna J. M. (1984) Emission Sources in the Soviet Union. TR Report 4/84. The Norwegian Institute for Air Research, Lillestrom. Norway.

Pacyna J. M. and Ottar B. (1985) Transport and chemical composition of the summer aerosol in the Norwegian Arctic. Atmospheric Environment 19, 2109-2120.

Pacyna J. M., Ottar B., Tomza U. and Maenhaut W. (1985) Long-range transport of trace elements of $\mathrm{Ny}$-alesund, Spitsbergen. Atmospheric Environment 19, 857-865.

Pacyna J. M., Bartonova A., Cornille P. and Mainhaut W. (1989) Modelling of long-range transport of trace elements: a case study. Atmospheric Environment 23, 107-114.

Raatz W. E. and Shaw G. E. (1984) Long range transport of pollution aerosol into the Alaskan Arctic. J. Clim. appl. Met. 23, 1052-1064.

Rahn K. A. (1981a) The Arctic air-sampling network in 1980. Atmospheric Environment 15, 1349-1352.

Rahn K. A. (1981b) Atmospheric riverine and oceanic sources of seven trace metals to the Arctic Ocean. Atmospheric Environment 15, 1507-1516.

Rahn K. A. (1982) On the causes, characteristics and potential environmental effects of aerosol in the Arctic atmosphere. In Proc. Conf. on the Arctic Ocean: the Hydrographic environment and the Fate of Pollutants (edited by Rey L. and Stonehouse B.). pp. 163-195. Macmillan Press, London.

Rahn K. A. and McCaffrey R. J. (1980) On the origin and transport of the winter Arctic aerosol. Ann. N. Y. Acad. Sci. 338, 486-503.

Slinn W. G. N. et al. (1978) Some aspects of the transfer of atmospheric constituents past the air-sea interface. Atmospheric Environment 12, 2055-2087.

Sturges W. T. and Barrie L. A. (1989) Stable lead isotope ratios in Arctic aerosol-evidence for the origin of the pollutants. Atmospheric Environment 23, 2513-2519.

Sturges W. T., Hopper J. F., Barrie L. A. and Schnell R. C. (1994) Stable lead isotope ratios in Alaskan Arctic aerosols. Atmospheric Environment 27A, 2865-2871.

Weiss H. V., Herron M. M. and Langway C. C. (1978) Natural enrichments of elements in snow. Nature 274, 352-353. 